\title{
Ocena dostępności usług opieki psychiatrycznej
}

\section{Assessment of the availability of mental health services}

\author{
Marta Bażydło, Beata Karakiewicz \\ Katedra i Zakład Zdrowia Publicznego Pomorskiego Uniwersytetu Medycznego w Szczecinie \\ ul. Żołnierska 48, 71-210 Szczecin \\ Kierownik: prof. dr hab. n. zdr. Beata Karakiewicz
}

\begin{abstract}
SUMMARY
Introduction: The aim of the study was to assess the availability of care for people with mental illness in Western Pomerania, Poland.

Material and methods: The study was designed as a diagnostic survey. It was conducted among representatives of health care facilities providing mental health care services under a contract with the National Health Fund.

Results: Respondents were asked to assess the availability of services at their institution. Very good availability of facilities was indicated by more than half of respondents (58\%), and satisfactory availability by $35 \%$. None of the respondents indicated poor availability, one respondent answered 'do not know', and one marked no answer. Respondents were asked to assess the
\end{abstract}

\section{STRESZCZENIE}

Wstęp: Celem pracy było określenie stopnia dostępności opieki dla osób z zaburzeniami psychicznymi w województwie zachodniopomorskim.

Materiał i metody: Wybraną metodą był sondaż diagnostyczny. Został on przeprowadzony wśród przedstawicieli placówek opieki zdrowotnej świadczących usługi opieki psychiatrycznej w ramach kontraktu z Narodowym Funduszem Zdrowia.

Wyniki: Ankietowanych zapytano, jak oceniają dostępność usług reprezentowanej przez siebie placówki. Ponad połowa respondentów (58\%) oceniła dostępność do reprezentowanej przez siebie placówki jako wysoką, 35\% jako średnią, nikt nie ocenił dostępności jako niskiej, jeden respondent zaznaczył odpowiedź „trudno powiedzieć”, a jeden nie zaznaczył żadnej odpowiedzi. Respondentów zapytano również, jak oceniają sytuację opieki psychiatrycznej pod kątem jej dostępności. Oddzielnie zapytano situation of mental health care in Western Pomerania. They were asked to assess the availability of outpatient care, and separately to assess the availability of inpatient care. Almost every fifth respondent (19\%) rated the availability of outpatient care as good, $61 \%$ as satisfactory, $13 \%$ as poor, and $7 \%$ of surveyed subjects had no opinion. The availability of inpatient care was rated good by $16 \%$ of respondents. Most respondents, $55 \%$ rated it as satisfactory, and $26 \%$ of respondents rated it as poor. One respondent did not have an opinion on this subject.

Conclusions: 1 . The respondents positively assess the availability of the institutions they represent. 2 . Access to mental health care across the whole region is assessed as satisfactory. 3. Access to outpatient care is better assessed than residential care.

Key words: health services availability, mental health services.

o ocenę dostępności do opieki ambulatoryjnej, a także o ocenę dostępności do opieki stacjonarnej i całodobowej. Niemalże co piąty pytany (19\%) ocenił dostępność ambulatoryjnej opieki jako dobrą, $61 \%$ jako średnią, $13 \%$ jako złą, 7\% osób nie miało zdania. Dostępność do opieki stacjonarnej i całodobowej 16\% respondentów oceniło jako dobrą. Najwięcej respondentów (55\%) oceniło ją jako średnią, a 26\% pytanych oceniło jako złą. Jeden respondent nie miał opinii na ten temat.

Wnioski: 1. Przedstawiciele placówek świadczących usługi opieki psychiatrycznej dobrze oceniają dostępność do reprezentowanych przez siebie placówek. 2. Dostępność do opieki psychiatrycznej na terenie całego województwa respondenci oceniają jako średnią. 3. Dostępność do opieki ambulatoryjnej jest lepiej oceniana niż do opieki stacjonarnej i całodobowej. Słowa kluczowe: dostępność opieki zdrowotnej, opieka psychiatryczna.

\section{WSTĘP}

Szybkie tempo życia i zmiany, jakie niesie ze sobą rozwój technologii, powodują wzrost ryzyka wystąpienia zaburzeń psychicznych. Potwierdzają to dane epidemiologiczne, zgodnie z którymi wzrasta liczba osób cierpiących na zaburzenia psychiczne i liczba zgonów z nimi związanych. W skali świata, zgodnie z doniesieniami Światowej Organizacji Zdrowia (World Health Organization - WHO), zaburzenia psychiczne, nerwowe i problemy psychospołeczne dotykają $450 \mathrm{mln}$ osób [1]. Tak duże rozpowszechnienie zaburzeń psychicznych powoduje finansowe obciążenie opieki zdrowotnej. Warto przy tym zauważyć, że w Europie środki finansowe przeznaczane na opiekę psychiatryczną stanowią 5,8\% wydatków na opiekę zdrowotną [2].

W Polsce problem zaburzeń psychicznych dotyczy 15-25\% populacji. W Polsce w latach 1990-2007 nastąpił wzrost rozpowszechnienia zaburzeń psychicznych o $119 \%$ w opiece ambulatoryjnej i o 50\% w opiece stacjonarnej. W latach 1991-2002 podwoił się odsetek osób podejmujących leczenie ze względu na zaburzenia psychiczne. W piśmiennictwie jako przyczynę tak dużego wzrostu wskazuje się transformację ustrojową. Warto zwrócić uwagę na fakt, że województwo zachodniopomorskie boryka się 
z innym, bardzo istotnym problemem społecznym, jakim jest niemal najwyższy w kraju odsetek osób bezrobotnych $(16,4 \%)$, co może również nasilić występowanie zaburzeń psychicznych. Jednocześnie z wyników badań wynika, że aż 45\% dorosłych Polaków obawia się o swoje zdrowie psychiczne [3, 4, 5].

Biorąc pod uwagę powyższe dane epidemiologiczne, zagadnienie dostępności psychiatrycznej opieki zdrowotnej nabiera szczególnego znaczenia. Nie istnieje jedna, wyczerpująca definicja dostępności opieki zdrowotnej. Warto jednak powołać się na R.S. Maxwella, który określił dostępność jako stopień łatwości korzystania z opieki, biorąc pod uwagę bariery zarówno finansowe, organizacyjne, kulturowe, jak i emocjonalne [6]. Dostępność jest jednocześnie jednym z elementów jakości opieki [6, 7]. Należy podkreślić, że na dostępność składa się wiele czynników. Wśród nich znajduje się m.in. lokalizacja placówki, mobilność pacjenta, czas i wysiłek, które pacjent musi poświęcić, by móc skorzystać z usług, a także cena świadczeń $[7,8,9,10]$. Podniesienie dostępności opieki zdrowotnej dla wszystkich grup społecznych, czyli ograniczenie nierówności w zdrowiu, jest jednym z celów polityki społecznej Unii Europejskiej [11]. W Polsce konstytucyjnym prawem każdego obywatela jest równy dostęp do świadczeń opieki zdrowotnej finansowanych ze środków publicznych, na warunkach i w zakresie określonych w ustawie [12].

Problem narastania liczby osób z zaburzeniami psychicznymi uwzględniono w Narodowym Programie Zdrowia na lata 2007-2015, którego czwartym celem strategicznym jest zapobieganie zaburzeniom psychicznym przez działania prewencyjno-promocyjne. Z kolei w ósmym celu omówione zostało zmniejszenie różnic społecznych i terytorialnych w stanie zdrowia populacji [13].

W Polsce w 2010 r. wszedł w życie na drodze rozporządzenia Rady Ministrów Narodowy Program Ochrony Zdrowia Psychicznego. Drugi cel główny programu zakłada zapewnienie osobom z zaburzeniami psychicznymi wielostronnej, powszechnie dostępnej opieki zdrowotnej, a także innych form opieki oraz pomocy niezbędnych do życia w środowisku rodzinnym i społecznym. Cel ten ma być zrealizowany poprzez upowszechnienie środowiskowego modelu psychiatrycznej opieki zdrowotnej, upowszechnienie zróżnicowanych form pomocy i oparcia społecznego, skoordynowanie różnych form opieki i pomocy [3]. W celu realizacji tych zadań w województwie zachodniopomorskim powstał Regionalny Program Ochrony Zdrowia Psychicznego dla województwa zachodniopomorskiego na lata 2011-2015, którego głównym celem jest dążenie do zapewnienia równej dostępności do psychiatrycznych świadczeń zdrowotnych [14].

Celem pracy było określenie stopnia dostępności opieki dla osób z zaburzeniami psychicznymi w województwie zachodniopomorskim.

\section{MATERIA I METODY}

W celu określenia dostępności psychiatrycznej opieki zdrowotnej badaniami objęte zostały placówki opieki psychiatrycznej znajdujące się na terenie województwa zachodniopomorskiego. Wybraną metodą był sondaż diagnostyczny. Został on przeprowadzony wśród przedstawicieli placówek opieki zdrowotnej mających zawarty kontrakt z Narodowym Funduszem Zdrowia (NFZ) na świadczenie usług opieki psychiatrycznej w 2012 r. Do badania włączono zarówno placówki opieki otwartej, jak i zamkniętej. W placówkach znajdujących się na terenie Szczecina przeprowadzono wywiad wspomagany autorskim kwestionariuszem ankiety, do placówek znajdujących się poza Szczecinem kwestionariusze zostały wysłane pocztą, po uprzedniej rozmowie telefonicznej. Badanie było badaniem pełnym - włączono do niego wszystkie placówki opieki psychiatrycznej świadczące usługi w ramach kontraktu z NFZ. Udział w badaniach wzięło 40\% z tych placówek, czyli 31. Ze względu na małą liczbę placówek nie przeprowadzono analizy statystycznej uzyskanych wyników.

\section{WYNIKI}

W trakcie badań skontaktowano się telefonicznie ze wszystkimi placówkami opieki psychiatrycznej w województwie zachodniopomorskim. Spośród 78 placówek na udział w badaniach zgodziło się 31 (40\%). Liczba placówek objętych badaniem znajdujących się na terenie Szczecina wynosiła 14 (spośród łącznie 17 placówek znajdujących się w Szczecinie), natomiast poza Szczecinem położonych było 17 placówek (spośród 61 placówek spoza Szczecina).

Spośród badanych placówek 13 (42\%) świadczyło tylko jedną formę opieki. W przypadku 9 placówek była to poradnia zdrowia psychicznego oraz 1 poradnia terapii uzależnienia i współuzależnienia od alkoholu, 1 poradnia terapii uzależnienia od substancji psychoaktywnych, 1 zakład pielęgnacyjno-opiekuńczy psychiatryczny i 1 ośrodek rehabilitacji dla osób uzależnionych od substancji psychoaktywnych. Pozostałe 18 placówek oferowało różne formy opieki psychiatrycznej.

Najwięcej placówek oferowało świadczenia poradni zdrowia psychicznego (23), poradni terapii uzależnienia i współuzależnienia od alkoholu (7) oraz poradni psychologicznej. Najrzadziej oferowane świadczenia to świadczenia poradni leczenia uzależnień (1), świadczenia oddziału leczenia alkoholowych zespołów abstynencyjnych - detoksykacja (1), program leczenia substytucyjnego (1), oddział rehabilitacji psychiatrycznej (1); 23 placówki świadczyły opiekę tylko otwartą (ambulatoryjną), 6 - opiekę ambulatoryjną i całodobową, a 2 tylko opiekę całodobową.

\section{Personel}

W badanych placówkach zatrudnionych było 112 psychiatrów, 11 psychiatrów dzieci i młodzieży, 214 pielęgniarek, 30 pielęgniarek psychiatrycznych, 27 psychologów klinicznych, 67 psychologów, 79 psychoterapeutów, 35 terapeutów zajęciowych, 15 pracowników socjalnych. Przedstawicieli placówek zapytano, czy liczba pracowników jest wystarczająca. Dla 71\% (22) respondentów liczba ta była wystarczająca, dla 16\% (5) nie, $13 \%$ (4) osób nie miało zdania na ten temat. 


\section{Okres oczekiwania}

Spośród przedstawicieli 29 placówek świadczących opiekę ambulatoryjną 59\% (17) zdeklarowało, że czas oczekiwania pacjenta na pierwszą wizytę wynosi do tygodnia. W 14\% (4) placówek średni czas oczekiwania wynosi do miesiąca. W 10\% placówek (3) czas ten wynosi do 2 miesięcy, a w przypadku 7\% (2) placówek - do 3 miesięcy. W jednej z placówek średni czas oczekiwania wynosi 3,5 miesiąca. Przedstawiciele 14\% (4) placówek zaznaczyli, że czas oczekiwania zależy od tego, z jakiej usługi pacjent chce skorzystać. Dwoje respondentów nie udzieliło odpowiedzi na to pytanie.

Na świadczenia opieki stacjonarnej i całodobowej udzielane przez 8 placówek okres oczekiwania wynosi do tygodnia w 2 placówkach, do miesiąca w jednej placówce, do 3 miesięcy w 2 placówkach i ponad 3 miesiące w jednej placówce (w żadnej placówce okres ten nie wynosi do 2 miesięcy). W 2 placówkach okres ten zależy od usługi, z jakiej pacjent chce skorzystać.

\section{Liczba porad/miejsc w placówkach}

Respondentów zapytano, czy planowane jest zwiększenie liczby udzielanych porad. Spośród 29 placówek świadczących opiekę ambulatoryjną, 31\% (9) zadeklarowało chęć zwiększenia liczby udzielonych porad, $38 \%$ (11) respondentów nie miało zdania na ten temat. W 31\% (9) placówkach nie jest planowane zwiększenie liczby udzielanych porad. W pytaniu otwartym o uwagi 9 (31\%) respondentów zaznaczyło, że faktyczne zwiększenie liczby udzielanych porad zależy od kontraktu z NFZ.

W badanych placówkach 8 świadczyło opiekę stacjonarną. $\mathrm{W}$ ani jednej z tych form opieki nie było wolnego miejsca. Tylko 1 respondent zdeklarował, że w placówce planowane jest zwiększenie liczby miejsc dla pacjentów; 3 respondentów odpowiedziało, że zwiększenie liczby miejsc nie jest planowane, a 4 respondentów nie miało zdania na ten temat. Jednocześnie 3 respondentów zaznaczyło, że decyzja o zwiększeniu liczby miejsc zależy od NFZ.

\section{Ocena dostępności}

Ankietowanym zadano pytanie, jak oceniają dostępność usług reprezentowanej przez siebie placówki. Możliwe do wyboru odpowiedzi były następujące: wysoka, średnia, niska, trudno ocenić. Ponad połowa pytanych, czyli 58\% (18 osób), oceniło dostępność do reprezentowanej przez siebie placówki jako wysoką, 35\% (11 osób) jako średnią, nikt nie ocenił dostępności jako niskiej, 1 respondent zaznaczył odpowiedź „trudno powiedzieć", a 1 nie zaznaczył żadnej odpowiedzi.

Spośród placówek, które oceniły dostępność jako wysoką, 50\% (9) znajdowało się w Szczecinie i 50\% (9) poza. Spośród tych placówek 56\% (10) oferowało więcej niż jedną formą pomocy, a 44\% (8) jedną formę pomocy (5 poradni i ośrodek rehabilitacyjny dla uzależnionych od substancji psychoaktywnych).

Spośród placówek, które oceniły dostępność swoich usług jako średnią, 45\% (5) znajdowało się w Szczecinie, a 55\% (6) poza; 45\% (5) spośród tych placówek oferowało więcej niż jedną formę pomocy, a 55\% (6) jedną (5 poradni i zakład pielęgnacyjno-opiekuńczy).

\section{Ocena dostępności opieki ambulatoryjnej w województwie}

Respondentów zapytano także, jak oceniają sytuację opieki psychiatrycznej pod kątem jej dostępności w województwie zachodniopomorskim. Oddzielnie zapytano o ocenę dostępności do opieki ambulatoryjnej i oddzielnie o ocenę dostępności do opieki stacjonarnej i całodobowej. Możliwe warianty odpowiedzi to: dobra, średnia, zła, brak zdania.

Niemalże co piąty pytany (19\%, 6 osób) ocenił dostępność opieki ambulatoryjnej jako dobrą, 61\% (19) jako średnią, 13\% (4) jako złą, 2 osoby nie miały zdania. Kolejne pytanie dotyczyło tego, czy i jakie są bariery w dostępności do ambulatoryjnej opieki psychiatrycznej. W przypadku tego pytania możliwe było zaznaczenie więcej niż jednej odpowiedzi. Najwięcej, $42 \%$ (13) osób, wskazało, że jest to zbyt mała liczba zakontraktowanych porad. Dla 35\% (11) osób barierą jest brak przepływu informacji między placówkami. Kolejna najczęściej wskazywana bariera to zbyt mała liczba placówek 32\% (10) osób. Ponadto $10 \%$ pytanych (3 osoby) wskazało jako barierę nieodpowiednią lokalizację placówek, a 1 osoba wysoki koszt świadczeń. W pytaniu otwartym respondenci podawali następujące odpowiedzi: zbyt mała liczba lekarzy (2 osoby), brak przeciwdziałania stygmatyzacji osób chorych i niechęć z powodu stygmatyzacji do korzystania z poradni zdrowia psychicznego (4 osoby), ograniczenie liczby przyjęć w danym dniu przez NFZ (1 osoba). Jednocześnie 19\% pytanych (6 osób) odpowiedziało, że nie dostrzega barier w dostępie do ambulatoryjnej opieki psychiatrycznej.

Respondentów zapytano także o ocenę czasu oczekiwania na możliwość skorzystania z psychiatrycznej opieki ambulatoryjnej w województwie zachodniopomorskim. Możliwe odpowiedzi to: krótki, średni, długi, brak zdania. Niemalże co trzeci pytany (29\%, 9 osób) zaznaczył odpowiedź „krótki”; ten sam odsetek pytanych wskazał odpowiedź „średni”; 7\% (2) pytanych oceniło ten czas jako długi, a 35\% (10) osób nie miało zdania. Respondentów zapytano, co ich zdaniem powoduje wydłużenie czasu oczekiwania. Również w tym pytaniu respondenci mogli wskazać więcej niż jedną odpowiedź. Zgodnie z wynikami badań 39\% (12) osób wskazało mało miejsc w istniejących placówkach, 29\% (9 osób) zbyt małą liczbę placówek, a 23\% (7 osób) brak przepływu informacji między placówkami; $10 \%$ pytanych (3 osoby) wskazało wysoki koszt świadczeń, tyle samo osób wskazało nieumiejętne zarządzanie placówkami. W odpowiedziach otwartych 2 osoby wskazały niewystarczającą liczbę personelu.

\section{Ocena dostępności opieki stacjonarnej i całodobowej w województwie}

Analogiczne pytania zadano respondentom w odniesieniu do ich opinii na temat dostępności opieki stacjonarnej i całodobowej w województwie.

Dostępność do opieki stacjonarnej i całodobowej 16\% (5) respondentów oceniło jako dobrą. Najwięcej respondentów, $55 \%$ (17), oceniło ją jako średnią, a 26\% (8) pytanych oceniło ją jako złą. Jedna osoba nie udzieliła odpowiedzi na to pytanie. Najczęściej wskazywaną barierą w dostępie do tej formy 
opieki było mało miejsc w placówkach (55\%, 17 ankietowanych), kolejna odpowiedź to brak przepływu informacji między placówkami (26\%, 8 pytanych) oraz mała liczba placówek (26\%, 8 pytanych). Jednocześnie 16\% (5) respondentów wskazało nieprawidłową lokalizację placówek. Również 16\% (5) respondentów zaznaczyło, że nie dostrzega barier w dostępie do opieki. Dla 10\% (3) pytanych barierą jest wysoki koszt świadczeń. W odpowiedziach otwartych wskazywano lęk przed wizytą u psychiatry (1 osoba), niewystarczającą liczbę personelu (1 osoba), zbyt mało miejsc w placówkach opiekuńczo-leczniczych oraz rehabilitacji psychiatrycznej (1 osoba), mało miejsc w placówkach dla osób uzależnionych (2 osoby).

Kolejne pytanie dotyczyło oceny długości czasu oczekiwania na możliwość skorzystania z usług placówek stacjonarnych i całodobowych. Odpowiedź „krótki” wskazało 29\% (9), 13\% (4) pytanych oceniło ten czas jako długi, 23\% (7) jako średni, a $32 \%$ (10) nie miało zdania. Jako przyczyny wydłużonego czasu oczekiwania wskazywano: mało miejsc w placówkach (45\%, 14 osób), mało placówek (29\%, 9 osób), nieumiejętne zarządzanie placówkami (13\%, 4 osoby), brak przepływu informacji między placówkami (10\%, 3 osoby), wysoki koszt świadczeń ( $6 \%, 2$ osoby). W odpowiedziach otwartych wskazywano niewystarczającą liczbę personelu (2 osoby).

\section{DYSKUSJA}

Realizacja Narodowego Programu Ochrony Zdrowia Psychicznego oraz Regionalnego Programu Ochrony Zdrowia Psychicznego dla województwa zachodniopomorskiego wymaga dokładnej analizy obecnej sytuacji opieki psychiatrycznej. Wprowadzenie zmian organizacyjnych powinno być poprzedzone poznaniem opinii zarówno świadczeniodawców, jak i świadczeniobiorców. W badaniach własnych starano się poznać opinię świadczeniodawców na temat dostępności opieki psychiatrycznej [13].

Wyrażone przez respondentów opinie są zbieżne z zadaniami wyznaczonymi przez Narodowy i Regionalny Program Ochrony Zdrowia Psychicznego [14]. W przeprowadzonych badaniach jako główne bariery w dostępie do opieki psychiatrycznej wskazano zbyt małą liczbę zakontraktowanych porad, zbyt małą liczbę miejsc w istniejących placówkach, małą liczbę placówek stacjonarnych i całodobowych, niedostateczny przepływ informacji między placówkami.

Warto zauważyć, że o ile większość respondentów popiera zwiększenie liczby miejsc w placówkach i liczby udzielanych porad, o tyle jedynie $16 \%$ badanych zauważa potrzebę zwiększenia liczby personelu, a jest to jeden z podstawowych celów Regionalnego Programu Ochrony Zdrowia Psychicznego dla województwa zachodniopomorskiego.

Przedstawione wyniki badań stanowią jedynie pierwszy krok oceny dostępności opieki psychiatrycznej w województwie zachodniopomorskim. Kolejne etapy badań to wywiady zbiorowe w interdyscyplinarnym gremium złożonym z lekarza psychiatry, pielęgniarki psychiatrycznej, psychologa, pracownika socjalnego, prawnika, a także zbadanie opinii pacjentów opieki psychiatrycznej na temat jakości świadczonych usług.

\section{WNIOSKI}

1. Przedstawiciele placówek świadczących usługi opieki psychiatrycznej dobrze oceniają dostępność reprezentowanych przez siebie placówek.

2. Na ocenę dostępności usług swojej placówki nie wpływa fakt jej położenia w dużym mieście oraz oferowanie więcej niż jednej formy pomocy przez placówkę.

3. Dostępność do opieki psychiatrycznej na terenie całego województwa respondenci oceniają jako średnią.

4. Działania mające na celu poprawę dostępności opieki psychiatrycznej powinny przewidywać wzrost liczby zakontraktowanych porad, wzrost liczby miejsc w istniejących placówkach oraz wzrost liczby placówek opieki psychiatrycznej, a także poprawę przepływu informacji między tymi placówkami.

\section{PIŚMIENNICTWO}

1. World Health Organization. Mental Health Report 2001. Mental Health: new understanding, new hope. WHO, Geneva 2001, 9.

2. Herczyńska G., Czabała C., Namysłowska I.: Podjąć wyzwania, szukać rozwiązań - zdrowie psychiczne w centrum uwagi rządów państw europejskich. Post Psychiatr Neurol. 2005, 14 (3), 259-266.

3. Narodowy Program Zdrowia na lata 2007-2015 (załącznik do Uchwały Nr 90/2007 Rady Ministrów z dnia 15 maja 2007 r.).

4. Główny Urząd Statystyczny. Miesięczna informacja o bezrobociu rejestrowanym w Polsce w maju 2014 roku. http://stat.gov.pl/obszarytematyczne/praca-wynagrodzenia/bezrobocie-stopa-bezrobocia/ miesieczna-informacja-o-bezrobociu-rejestrowanym-w-polsce-w-maju2014-roku,1,28.html\# (24.07.2014 r.).

5. Wciórka B., Wciórka J.: Sondaż opinii publicznej - czy Polacy niepokoją się o swoje zdrowie psychiczne? Post Psychiatr Neurol. 2005, 14 (4), 305-317.

6. Ksykiewicz-Dorota A.: Zarządzanie w pielęgniarstwie. Podręcznik dla studentów studiów magisterskich Wydziałów Pielęgniarstwa oraz Wydziałów Nauk o Zdrowiu. Wyd. Czelej, Lublin 2005.

7. Czupryna A., Poździoch S., Ryś A., Włodarczyk W.C.: Zdrowie Publiczne, tom 2. Vesalius, Kraków 2001.

8. Rydz E.: Dostępność sfery usług z zakresu lecznictwa zamkniętego na przykładzie województwa pomorskiego. In: Zróżnicowanie przestrzenne sytuacji zdrowotnej, systemu bezpieczeństwa i usług medycznych w województwie pomorskim. Ed. T. Michalski. EJB, Gdynia 2002.

9. Łukomska A.: Dostępność świadczeń lekarza rodzinnego w ocenie pacjentów. Fam Med Prim Care Rev. 2000, 10 (2), 162-166.

10. Borek-Wojciechowska R., Kłokow S.: Dostępność świadczeń opieki zdrowotnej jako jeden z aspektów opieki. Zdr Publ. 2007, 117 (3), 381-385.

11. Bujalski M.: Bariery w dostępie do leczenia osób uzależnionych od alkoholu i narkotyków. Alkohol Narkom. 2008, 21 (4), 277-285.

12. Konstytucja Rzeczypospolitej Polskiej z dnia 2 kwietnia 1997 r. (Dz.U. Nr 78. poz. 483 ze zm.).

13. Rozporządzenie Rady Ministrów z dnia 28 grudnia 2010 r. w sprawie Narodowego Programu Ochrony Zdrowia Psychicznego (Dz.U. 2011 nr 24 poz. 128).

14. Regionalny Program Ochrony Zdrowia Psychicznego dla Województwa Zachodniopomorskiego na lata 2011-2015 (załącznik do uchwały Zarząd Województwa Zachodniopomorskiego Nr 2147/11 z dnia 22 grudnia 2011 r.). 